\title{
Cadmium Deposition
}

National Cancer Institute

\section{Source}

National Cancer Institute. Cadmium Deposition. NCI Thesaurus. Code C97098.

A finding indicating the presence of cadmium mineral deposits in an organ. 